\title{
Ples, igra, borba ili trka za vjeru \\ Sportski jezik kao starozavjetna biblijska metafora
}

\author{
Anđelo Maly* \\ angel5bible@yahoo.com \\ UDK: 81'373.612.2:27-242 \\ 394.3:27-242 \\ Pregledni članak / Review \\ Primljeno: 17. listopada 2017. \\ Prihvaćeno: 12. veljače 2018.
}

Počevši s predstavljanjem osobitosti ljudskog izražavanja riječima, odnosno jezikom, autor pokušava naglasiti funkciju metafore u jeziku općenito, a zatim to isto primjenjuje na jezik Starog zavjeta. Nakon što je izložio neke osobitosti semitskog načina razmišljanja i posebnosti povijesno-spasenjskoga značenja starozavjetnog jezika, autor se osvrće na kulturološku pozadinu Starog zavjeta kao konteksta u kojemu se stvaraju metafore. Jedan od posebnih, često zanemarenih konteksta Starog zavjeta je onaj igre i sporta. Biblijski čovjek dok pleše i igra se slavi Gospodina, ali takoder i trči i bori se za vjeru is vjerom na životnom borilištu da bi se opravdao i postojano hodio u Zakonu Gospodnjem te izrazio vlastitu vjeru. Uz pomoć biblijskih navoda o navedenim temama, autor pokušava objasniti kako su ples i igra, ali i oskudan sportski jezik, u Starom zavjetu korišteni ne samo kao autentičan način izražavanja odnosa s Gospodinom, već $i$ metafora koju biblijski autor razborito usvaja da bi opisao svoju vjeru.

Ključne riječi: Stari zavjet, semitski način razmišljanja, metafora, ples, igra, sport, vjera.

\footnotetext{
* Dr. sc. Anđelo Maly, poslijedoktorand na Katoličkom bogoslovnom fakultetu Sveučilišta u Zagrebu, Vlaška 38, pp 432, HR-10001 Zagreb.
} 


\section{Uvod}

Čim pojedinac uzme $\mathrm{u}$ ruke Sveto pismo ostaje iznenađen, ako ne i zaprepašten. Ova se činjenica možda više odnosu na Novi zavjet, ${ }^{1}$ dok su brojne stranice Starog zavjeta neupućenom čitatelju relativno nepoznate i neshvatljive. Jedan od razloga možda je i pastoralne naravi, ali je u većini slučajeva riječ o poteškoćama povezanima s jezikom Starog zavjeta, koji je kulturološki, gramatički i konceptualno mnogo dalji, ali naravno i stariji od našeg zapadnjačkog načina razmišljanja. Jezik se razvija, ali je uvijek jedno od temeljnih obilježja pojedinog naroda i ponajviše njegove kulture. Jezik nisu samo riječi, već su i slike, ideje, misli... odnosno sve ono što zrcali sva ljudska zbivanja, napore, uspjehe i neuspjehe, želje i ostvarenja, ili jednostavnije rečeno - jezik je neizostavan element ljudskog roda. Bez jezika, izraženog riječima, teško da bismo mogli komunicirati, sve bi ostalo na gestama i pretpostavkama što je netko želio reći. Jezik je antropološki fenomen, na temelju čega bismo možda mogli i parafrazirati Descartesov: »Cogito ergo sum « $\mathrm{u} »$ Loquor ergo sum«.

Jezikom, odnosno govorom, nastaje svijet (usp. Post 1, 3-31), ${ }^{2}$ a komunikacijom se održava (usp. Post 2, 19-20a). Drugim riječima: jezik ne koristi samo za oponašanje (mimesis) stvarnosti, štoviše on ju oblikuje (poiesis). ${ }^{3}$ Stoga je moguće reći da je jezik, odnosno riječ, ono što od kaosa stvara red u čovjekovoj stvarnosti. Čovjek na taj način ono što misli izgovara i iznosi (gr. ferō) kao prihvaćenu zbilju.

Ponekad se dogodi da pojedinac pokušava opisati stvarnosti koje ga nadilaze: Boga, vjeru, osjećaje, razne duhovne stvarnosti, pri čemu se ne služi uvijek jednostavnim i razumljivim jezikom, već koristi slikovit govor: usporedbe, slike, metafore... Upravo je ova posljednja - metafora (gr. metaferō = prenošenje, prijenos), ona jezična forma kojom pojedina riječ umjesto svoga prvobitnog značenja dobiva drugo značenje, ponajviše jer je govornik u svojoj

\footnotetext{
${ }^{1}$ Dok Stari zavjet jako oskudno govori o sportu i koristi sportski rječnik, postoji nekoliko monografija i članaka o sportskoj metafori u Novom zavjetu na koje ovdje upućujemo: V. C. PFITZNER, Paul and the Agon Motif. Traditional Athletic Imagery in the Pauline Literature, Leiden, Brill, 1967; M. ZOVKIĆ, Sportske igre kao izraz ljudske tjelesnosti i kao metafora u Bibliji, u: S. NIMAC (ur.), Tijelo, sport, teologija, Zagreb, Franjevački samostan Gospe Lurdske, 1988, 21-31; U. POPLUTZ, Athlet des Evangeliums. Eine motivgeschichtliche Studie zur Wettkampfmetaphorik bei Paulus, Freiburg, Herder, 2004; M. BRÄNDL, Der Agon bei Paulus. Herkunft und Profil paulinischer Agonmetaphorik, Tübingen, Mohr Siebeck, 2006; A. MALY, Dall'atleta incatenato al campione celeste. Escatologia e metafora agonistica nella Lettera ai Filippesi, Bologna, Edizioni Dehoniane, 2017.

2 Ovdje se misli na stvaralačku riječ Gospodinovu: »I reče Bog...«.

${ }^{3}$ Poplutz, Athlet des Evangeliums..., 20.
} 
misli usporedio dva predmeta. ${ }^{4}$ Metafora ovako popunjava praznine ${ }^{5} \mathrm{u}$ jeziku i nije dovoljna sama po sebi, jer polazi od iskustva i treba biti kontekstualizirana u društvenom i/ili vjerskom ambijentu. Nažalost, često se dogodi da je kontekst u kojemu se metafora koristi, ali i same riječi kojima se metafora izriče, neshvatljiv i višeznačan, napose ako je riječ o jeziku koji je dio nekog drugog svijeta i kulture. Takav drugačiji svijet i kultura su svakako oni koje susrećemo na stranicama Starog i Novog zavjeta.

Primjeri su brojni i neiscrpni. Stoga ćemo se u ovom radu pokušati osvrnuti na jedan od elemenata starozavjetnog jezika i pretpostavljene upotrebe metafore u vjerojatnom kulturološkom kontekstu sporta ${ }^{6}$ Starog zavjeta kako bismo ispunili praznine koje hermeneutika često izostavlja.

\section{Neki primjeri starozavjetnog (semitskog) načina izražavanja}

Dok suvremenog čitatelja Starog zavjeta zaokupljaju točne povijesne činjenice, relativno transparentan jezik i apsolutna istina koju želi znanstveno dokazati, semitski način razmišljanja mu u tome najčešće odmaže. Starozavjetni čovjek u razmišljanju i govoru više je nalik na djecu nego na odrasle ljude, više podsjeća na djecu ili na učenike u osnovnoj školi, nego na učene ljude. Izraelac ne razmišlja spekulativno, ne apstrahira niti stvara opće pojmove, već ostaje pri

\footnotetext{
${ }^{4}$ »Umjesto riječi koja se treba usporediti, jednostavno je došla riječ s kojom se ona uspoređuje, npr. »glava države« (umjesto vladar), »društveni talog « (umjesto ološ), »čelična volja« (umjesto nepokolebljiva volja)« (usp. Š. ANIĆ, N. KLAIĆ, Rječnik stranih riječi, Zagreb, Sani-Plus, 2002, 878).

${ }^{5}$ »Questo fenomeno va visto come un processo per mezzo del quale le immagini e le associazioni provenienti dall'esperienza, sviluppate a un livello in cui prevale una rete di associazioni sensoriali, vengono trasferite a un livello in cui i pensieri sono ordinati secondo una logica di categorie verbali « (B. E. BECK, La metafora come mediatore tra pensiero semantico e pensiero analogico, u: C. CACCIARI (ur.), Teorie della metafora. L'acquisizione, la comprensione e l'uso del linguaggio figurato, Milano, Raffaello Cortina, 1991, 312).

${ }^{6}$ Pod pojmom »sporta/športa« ovdje podrazumijevamo ono što navode rječnici: »Igra, šala, provod u prirodi; osobito: sve one tjelesne vježbe za koje je potrebna snaga, hrabrost, izdržljivost, okretnost i umijeće« (Anić, Klaić, Rječnik stranih riječi..., 1333). Naočigled se može učiniti da sport i vjera nemaju neke zajedničke poveznice, jer je ova posljednja više transcendentalno usmjerena, dok bi se sport mogao opisati unutar sekularnih kategorija. Međutim, ako bolje razmotrimo, i sport i vjera su usmjereni prema nečemu višemu što bi ljudski duh želio postići. Moguće je stoga promotriti relativno usku povezanost između sporta i vjere na nekoliko razina: a) povijesno, jer su se brojni sportovi razvili unutar religijskih slavlja; b) sportski se rječnik često koristi kao metafora u opisima za borbu ili nastojanje u vjeri; c) sportski događaji često su podrazumijevali snažnu privrženost, kao što je bio slučaj kod religijskih proslava; d) sport i religija simbolički predstavljaju sisteme koji naglašavaju slične vrijednosti i ciljeve, uključujući neke transcendentne osobne čežnje u svrhu stjecanja nematerijalnih nagrada ili iskustva kroz naglašenu osobnu ili skupnu žrtvu za dobrobit grupe ili zajednice; e) religija kao i sport prenosi svoju poruku snažnom simbolikom (usp. M. WOMACK, Sports and Religion, u: L. JONES (ur.), Encyclopaedia of Religion, sv. 13, Farmington Hills (MI), Thomson Gale, 2005, 8722-8723).
} 
konkretnim i pojedinim činjenicama. Apstraktni pojmovi poput Boga, čovjeka, grijeha, uvijek su konkretno određeni. Kad govori o čovjeku, on je uvijek konkretan čovjek: Adam, Abraham, David; ili kad govori o Bogu, Izraelac misli na konkretnog Boga koji se u povijesti Izraela objavio kroz spasenjska djela; kad govori o grijehu, misli na konkretne grijehe koje je počinio Izrael ili pojedini član izraelskog naroda. ${ }^{7}$

$\mathrm{S}$ jedne se strane Stari zavjet često služi se mitološkim jezikom i slikama, tako da poosobljuje prirodne pojave, ${ }^{8}$ eshatološko vrijeme opisuje kao povratak u rajsko stanje (Iz 11, 6-9), spaja božanske i ljudske sfere (usp. Post 6, 4), čime se riječima izražavaju transcendentalne stvarnosti. S druge strane, budući da čovjek ne može iskustveno doživjeti Boga, često mu pripisuje ljudske osobine i tako idealizira čovjeka, ali ujedno svjestan da ljudskim govorom ne može nikako izreći neizrecivu stvarnost Boga. ${ }^{9}$ Hebrejski način izražavanja i mišljenja je u potpunosti teocentričan, jer sve što se događa ovisi o Bogu, on je živa stvarnost. Rebić to sažimlje na sljedeći način:

»Ako Izraelac doživi neko dobročinstvo, onda za nj zahvaljuje Bogu. Budući da nije znao za pojam prirode kao što znamo mi danas zahvaljujući suvremenoj znanosti, gotovo svaki događaj pripisivao je izravno Bogu. Bog je onaj koji daje kišu i otvara nebo; on poziva u rat i kao kaznu nameće poraz nevjernom narodu. Kad se pobožni Izraelac osvrtao na prošlost i, na primjer, pripovijedao izlazak iz Egipta, činio je to sasvim u skladu sa svojim načinom mišljenja, u skladu s kojim je spasenjski zahvat Božji isticao neobičnim i čudesnim događajem. Samo je tako mogao, mislio je on, dostojno govoriti o Božjem djelovanju. ${ }^{10}$

Hebrejski se način izražavanja i razmišljanja značajno razlikuje od grčkog i našeg suvremenoga razmišljanja i izražavanja. U semitskom načinu razmišljanja najvažnije je bilo kroz pojedine izvještaje pronaći ono na što se bilo moguće pouzdati i što je pomagalo u oblikovanju njihova života. Izraelac je također bio manje zaokupljen vanjskom slikom i vanjskim izgledom te je osobe ili predmete opisivao prema njihovim svojstvima ili načinu ophođenja. S jedne strane, rijetko je u Bibliji detaljno opisan pojedini lik (kao, na primjer, David u 1 Sam 16, 12) i nigdje ne nalazimo kako su točno izgledali Abraham ili Mojsije ili Isus i apostoli. Isto tako ne znamo kako je točno izgledala dovršena Noina arka (usp. Post 6, 14-16) ili Hram (usp. 1 Kr 6, 1-38), imamo samo opis projekta ili procesa njihove gradnje. $S$ druge strane, rijetko se gdje spominje vanjski izgled pojedine osobe (npr. Mojsije dok silazi s brda: Izl 34, 30; Isus na brdu Preobraženja: Mk

\footnotetext{
7 Usp. A. REBIĆ, Središnje teme Starog zavjeta. Biblijskoteološki pregled starozavjetne poruke, Zagreb, Kršćanska sadašnjost, 1996, 12-13.

${ }^{8}$ Npr. sunce: Ps 19, 5c-6: »Ondje suncu razape šator, te ono k'o ženik iz ložnice ide, k'o div kliče kad prelijeće stazu«; jutarnje zvijezde: Iz 14, 12a: »Kako pade sa nebesa, Svjetlonošo, sine Zorin?« (Biblijski tekstovi preuzeti su iz A. REBIĆ (ur.), Stari zavjet s uvodima i bilješkama ekumenskog prijevoda Biblije, Zagreb, Kršćanska sadašnjost, 2011).

${ }^{9}$ Usp. Rebić, Središnje teme Starog zavjeta..., 15.

${ }^{10}$ Isto, 17.
} 
9, 3; Mt 17, 2; Lk 9, 29), ali to je uglavnom samo zato da se istakne njezino povijesno-spasenjsko značenje. ${ }^{11}$

\section{Neke odlike i poteškoće hebrejskog jezika}

Iz nekoliko navedenih primjera moguće je primijetiti da je hebrejski način izražavanja pun jezičnih prepreka. Naime, transparentnost bilo kojeg jezika vidljiva je na tri moguće razine: fonetskoj, morfološkoj i analoškoj, ${ }^{12}$ ali s hebrejskim imamo neke poteškoće. Fonetska transparentnost jezika očituje se, na primjer, u onomatopeji koja je jako rijetka u hebrejskom jeziku, jer ona podrazumijeva stanovitu komponentu konvencionalnosti samog jezika. U Engleskoj tvrde da pijetao pjeva cockadoodledoo, u Francuskoj cocorico, u Njemačkoj i Grčkoj kikeriki, u Italiji chicchirichì, a u Hrvatskoj kukuriku..$^{13}$ Onomatopeja se pretežito temelji na vokalima, dok su nositelj hebrejskih riječi konzonanti, a vokalizacija se uglavnom mijenja ovisno o deklinaciji/konjugaciji, što je vjerojatno prilikom vokalizacije teksta dovelo do poteškoća u razumijevanju nekih izraza.

Morfološka transparentnost jezika važnija je od fonetske, jer ona ovisi o procesu oblikovanja pojedinih riječi. Tko pozna značenje neke riječi, sposoban je stvoriti njezine izvedenice iz samog korijena te riječi, gdje je korijen nositelj temeljnog značenja riječi. Tako se, na primjer, od korijena riječi rat- mogu stvoriti čitavi nizovi riječi: rat-ni, rat-ovanje, rat-nik, rat-nički, pred-rat-ni, ratoboran itd.; sve ove riječi su srodne. U grčkom jeziku je već drugačij. Grčke imenice haris (milost) i hara (radost) dolaze od istoga glagola hairein (= veseliti se; radovati se; biti zdrav; pozdraviti). Hebrejski ima neke posebne odlike morfološke transparentnosti, od kojih je prva etimološka. Tako, na primjer, Bog u Post 2, 7 oblikuje čovjeka - Adama (heb. 'adam) od zemlje (heb. 'adamah); Neftali u Post 30, 8 dobiva ime jer se Rahela borila (heb. nafal) protiv Lee i pobijedila; riječi koje Izaija upućuje Ahazu u Iz 7, 9b temelje se na etimologiji dviju glagolskih formi istoga korijena, ali različitoga značenja: »Ako se na mene ne oslonite (ta’aminu), održat' se (téamenu) nećete«. Drugi element morfološke transparentnosti ovisi o gramatičkoj i/ili sintaktičkoj strukturi hebrejskog jezika u kojemu, na primjer, neki glagol u isto vrijeme, ali u drugačijem kontekstu, može izricati prošlost, sadašnjost i budućnost. ${ }^{14}$

Treća i posljednja moguća vrsta jezične transparentnosti je analoška. Poznato je da većina jezika posjeduje brojne riječi čije značenje može imati obilježje metafore, odnosno da obična riječ ima preneseno značenje. Naime, neka se ri-

\footnotetext{
${ }^{11}$ Isto, 17.

${ }^{12}$ Usp. G. B. CAIRD, Lingua e linguaggio figurato nella Bibbia, Brescia, Paideia, 2009, 113-120.

${ }^{13}$ Isto, 114.

${ }^{14}$ Ovdje je možda potrebno napomenuti upotrebu wāw consecutivuma (s imperfektom ili perfektom) kojim se židovski autor koristi da bi opisao logičan slijed radnji koje prethode ili slijede naraciji [vidi W. GESENIUS, Gesenius Hebrew Grammar, (ur. E. KAUTZSCH), New York, Dover Publications, 2006, \$111-112].
} 
ječ zamjenjuje drugom čije je doslovno značenje slično značenju riječi koju ona nadomješta, ponajviše stoga da se stilistički izrazi kratka usporedba između dvaju elemenata nekog izričaja. Metafora je tako najčešće smještena u kontekst kojim je ona određena i kao takva treba biti shvaćena s drugačijim značenjem od izvornog i osnovnog značenja te iste riječi. ${ }^{15}$

Metaforu je moguće definirati i kao sliku koju je potrebno promatrati kroz povećalo, navodi se slušatelje da se više koncentriraju na predmet koji promatraju nego na povećalo, kao da im onaj koji se koristi metaforom govori: »Gledajte kroz ovo povećalo i vidite što sam ja vidio, ono što ne biste vidjeli bez povećala. «16 Neki od primjera su sljedeći: »Posijali su vjetar i požet će oluju« $\left(\right.$ Hoš 8, 7a) $;{ }^{17}$ »Tobolac mu je rastvoren grob « $(J r 5,16 a) ;{ }^{18} » Z$ Začeste sijeno, rodit ćete slamu... narodi će biti sažgani u vapno« (Iz 33, 11a.12a); ; ${ }^{19}$ Jer ti si moje stvorio bubrege, satkao ${ }^{20}$ me u krilu majčinu. Hvala ti što sam stvoren tako čudesno... Kosti moje ne bjehu ti sakrite dok nastajah u tajnosti, otkan u dubini zemlje« (Ps 139, 13-15); »Na njihova vijećanja mojim duhom ne silazio, u njihovim zborovima udjela nemao « (Post 49, 6a); »Gospodin neka bude sudac, on neka sudi između mene i tebe, neka ispita i brani moju stvar i neka mi pribavi pravdu: neka me izbavi iz tvoje ruke« (1 Sam 24, 16).

Kao što je moguće primijetiti iz ovih nekoliko primjera, metaforički je govor preuzet iz mitologije ili iz pravnog i ratničkog područja. Uobičajeno je bilo opisivati pravne slučajeve kao bitku između optuženika i tužitelja, jer su upravo ratovi i borbe bili kontekst u kojemu se starozavjetni čovjek često nalazio (vidi posljednja dva primjera). Stoga se upotrebljavao ratnički jezik da bi se opisali sudski procesi ili obratno. ${ }^{21}$ Metafora ovime dobiva socijalnu dimenziju kojom karakterizira kontekst u kojemu nastaje. Slično se može govoriti i o sportskom jeziku kao o često zanemarenoj starozavjetnoj metafori. ${ }^{22}$

\footnotetext{
${ }^{15}$ H. WEINRICH, Metafora e menzogna. La serenità dell'arte, Bologna, Il Mulino, 1967, 76.

${ }^{16}$ Caird, Lingua e linguaggio figurato nella Bibbia..., 191.

${ }^{17}$ Uzaludna sadnja nasada, koji, i ako uspiju, neprijatelj će uništiti.

${ }^{18}$ Strjelice naroda koje nepogrešivo donose smrt.

${ }^{19}$ Vjerojatno se smatra kako će neprijatelji biti okrutni jedni prema drugima i neće im biti nikakve pomoći.

${ }^{20}$ Prema Job 10, 11. Psalmist se ovdje predstavlja kao embrij koji raste u majčinoj utrobi te kao glina koja dobiva svoj oblik u rukama onoga koji ju oblikuje. Posljednji je element mitološki prema kojemu sve dolazi iz kozmičke utrobe majke zemlje.

${ }^{21}$ Usp. Caird, Lingua e linguaggio figurato nella Bibbia..., 190-191.

${ }^{22}$ Ovdje koristimo izraz »zanemarena « zato što se starozavjetna antropologija u teološkim rječnicima uglavnom bavi tematikama ljudske duhovnosti i tjelesnosti, jednako kao što se govori o čistoći i nečistoći ljudskog tijela, dok se o sportu mogu pronaći tek neke natuknice pod pojmovima igre, trčanja ili borbe.
} 


\section{Govor o sportu u Starom zavjetu}

Proučavajući Stari zavjet, na prvi se pogled čini da nije moguće opaziti sportski natjecateljski duh kao ni kult lijepoga. Ovdje je važno napomenuti poimanje starozavjetne antropologije prema kojoj je čovjek $u$ isto vrijeme »tijelo« (bāśār), kao stvorenje upućeno na Boga i bližnjega, sklono smrtnosti i bolesti, ali je također i »duh/duša« (nepeš), jer u njemu je duh životni (usp. Post 2,7 ). Ljudska tjelesnost podloga je čovjekove fizičke i moralne slabosti (usp. Ps $38,3-5)$. Ali čovjek može jačati i napredovati, odnosno treba se razvijati ${ }^{23}$ i tjelesno i duhovno, jednako na društvenoj i na religijskoj dimenziji. Baština židovskog naroda sadržana je na stranicama Starog zavjeta i opisuje tradiciju koja se proteže nekoliko tisuća godina, svjedoči o životu i vjeri tog naroda. Tako se u nekim starozavjetnim tekstovima, uz govor o ljudskoj osobi, životu i kultu, može naslutiti i govor o sportu. Također, govoreći o sportu i sportskom rječniku u Starom zavjetu, neizostavno je potrebno spomenuti i zapise u kojima prevladava spominjanje društvenih trenutaka plesa i igre, najčešće povezanih $\mathrm{uz}$ proslave $\mathrm{u}$ čast Gospodina Boga. ${ }^{24}$

\section{Ples i igra u Starom zavjetu}

Biblijski starozavjetni tekstovi spominju plesanje u različitim kontekstima kao važan obredni čin, ali i kao način iskazivanja radosti. Međutim, većina biblijskih tekstova ne opisuje način na koji su se ti plesovi odvijali, nego samo koristi različite glagole koji označavaju plesnu aktivnost: npr. śăhaq (piel: »razveseljavati igranjem«); kārar (pilpel: »plesati«); pāzaz (piel: »skočiti«); rāqad (piel: »plesati $\ll)^{25}$

Već na samome početku Starog zavjeta, točnije u Knjizi izlaska, nakon izvještaja o prelasku preko Crvenog mora, u trenutku pjesme zahvale za izbavljenje, opisuje se ples koji počinje Mojsijeva sestra Mirjam:

»Tada Aronova sestra, proročica Mirjam, uze bubanj u ruku, a sve žene pridruže joj se s bubnjem u ruci i s plesanjem« (Izl 15, 20).

Ovdje se ovdje koristi imenica $m^{e} h \bar{o} l \bar{a}^{h}$ (plesanje) koja opisuje radosno skakutanje nakon pobjede (usp. Suci 11, 34; 1 Sam 21, 21; 29, 5). Plesanje se spominje kao čašćenje Boga u proslavama (usp. Suci 21, 21) ili čak kao čin bezbožnosti (usp. Izl 32, 19). Ples se odvijao uz zvuke bubnjeva i različitih instrumenata,

\footnotetext{
${ }^{23}$ Usp. Zovkić, Sportske igre kao izraz ljudske tjelesnosti..., 22-23.

${ }^{24}$ D. NOVAK, Kršćanstvo i sport, Društvena istraživanja, 18 (2009) 1-2, 287-308, 293.

${ }^{25}$ Usp. D. LAPSON, A. SHILOAH, Dance, u: F. SKOLNIK, M. BERENBAUM (ur.), Encyclopaedia Judaica, sv. V, Farmington Hills (MI), Thomson Dale, ${ }^{22007, ~} 409$.
} 
a najviše opisa plesanja spominje se u vrijeme kralja Davida, ${ }^{26}$ za kojega se i samoga spominje da je plesao, odnosno igrao s cijelim narodom: ${ }^{27}$

»A kad je kovčeg Gospodnji ulazio u Davidov grad, Šaulova je kći Mikala gledala kroz prozor i vidjela kralja Davida kako skače i vrti se $\left(m^{\curvearrowright} f a z z e \bar{z}\right.$ ûmํㅡarkêr) pred Gospodinom« (2 Sam 6, 16).

»Kad je Kovčeg saveza Jahvina ulazio u Davidov grad, Šaulova kći Mikala, gledajući s prozora, vidje kralja Davida kako pleše i igra $\left(m^{\curvearrowright} r a q q e \bar{d} \underline{u}\right.$ ùmśahēq) te ga prezre ona u svom srcu« (1 Ljet 15, 29).

Brojni psalmi spominju plesanje i igru, kao na primjer Ps 87, 7a: »I pjevat će igrajući kolo« (usp. Ps 30, 12; 87, 7; 149, 3; 150, 4). Autori ovdje koriste imenicu $m a \bar{a} h \hat{o} l$ (ples), koji označava plesanje u grupi ili glagol ḥ̂ेl koji znači »okretati se u krug; plesati ${ }^{28}$

U Starom zavjetu pronalazimo također i četiri mjesta na kojima se upotrebljava glagol hhûl sa metaforičkim značenjem. ${ }^{29} \mathrm{U}$ tekstu Hoš 11,6 metaforički se opisuje bjesnilo mača protiv izraelskih gradova, dok se kod Jr 29, 19; 30, 23 vjetar razmahuje plešući nad bezbožnicima kao kazna. Izričito je snažna upotreba glagola hî̀l u opisu Abnerovog ubojstva u 2 Sam 3, 28-30, gdje Abnerova krv treba pasti (dosl. »razmahivati se«) na njegove ubojice. Ples je ujedno i znak patnje i boli koji prestaju: ${ }^{30}$

»Okrenuo si moj plač u igranje (l'māhhôl $)$,

skinuo kostrijet s mene

i opasao me radošću.

Zato ti pjeva duša moja i neće zamuknuti:

Jahve, Bože moj, dovijeka ću te hvaliti« (Ps 30, 12-13).

Iz posljednjeg primjera moguće je iščitati da starozavjetni čovjek koji polaže sve svoje vjerovanje u Gospodina, čak i nakon trenutaka nevolje i boli (ali i u njima), može u radosnom igranju/plesanju iskazati svoju hvalu. $\mathrm{Na}$ ovaj način ples je metafora za izražavanje vjere i hvale Bogu.

Uz glagol hûul u hebrejskom jeziku postoji još jedan sličan glagol, a to je śāḥaq koji je moguće prevesti kao »smijati se (qal); igrati (pi); razveseljavati igranjem; pridonositi dobrom raspoloženju«. Glagol שָ ima još jednu sličnu formu צחק $(s, h q)$ koja je u korijenu imena Izak, Abrahamovog sina. Izak se dakle »smije; on se igra «, on je radost; a i igra se zajedno s Jišmaelom (Post 21, 9: »Jednom opazi Sara gdje se sin koga je Egipćanka Hagara Abrahamu rodila igra s njezinim si-

\footnotetext{
${ }^{26}$ »David može izjaviti da pred Jahvom pleše jer zna da taj čin ima vrijednost vjerske žrtve. Baalovi proroci plesali su pred žrtvenikom svoga boga $(1 \mathrm{Kr} 18,26)$ « (M. COCAGNAC, Biblijski simboli, Zagreb, Antibarbarus, 2002, 274).

${ }^{27}$ Novak, Kršćanstvo i sport..., 294.

${ }^{28}$ Vidi H. EISING, חוּ - hûl, u: G. J. BOTTERWECK, H. RINGGREN, H.-J. FABRY (ur.), Theological Dictionary of the Old Testament, IV, Grand Rapids (MI), Eerdmans, 1980, 260-264.

${ }^{29}$ Isto, 261.

${ }^{30}$ Cocagnac, Biblijski simboli..., 275.
} 
nom Izakom «) kao što se djeca često igraju i raduju u biblijskim opisima. Prorok Zaharija tako govori o eshatološkom vremenu u kojemu će na sve strane biti igra i radost: »A gradski će se trgovi ispuniti dječacima i djevojčicama koji će se igrati na njegovim trgovima « (Zah 8,5$)$.

Židovi su također poput ostalih naroda poznavali različite igre: bile su to uglavnom igre zagonetki (usp. Suci 14, 12-20; $1 \mathrm{Kr}$ 10, 1-3), kao i neke ratničke igre poput konjskih utrka (usp. Jr 12, 5) ili mačevanja (usp. 2 Sam 2, 14-16). ${ }^{31}$ Pretpostavlja se da je većina ovih igara imala za cilj mentalno ili vojno usavršavanje, više nego zabavu. Osim spomenutih oblika igre, u mudrosnoj književnosti Starog zavjeta pored Boga Stvoritelja opisuje se i Mudrost koja se igra: ${ }^{32}$

»Bila sam kraj njega, kao graditeljica, bila u radosti, iz dana u dan, igrajući pred njim sve vrijeme: igrala sam po tlu njegove zemlje, i moja su radost djeca čovjekova« (Mudr 8, 30-31).

Mudrost je uz Boga ne samo kao graditeljica u strogom smislu riječi, već je opisana poput djeteta koje se igra (hebrejski tekst oba puta koristi glagol śāhaq) sa svijetom i u svijetu (autor koristi prijedlog ב ב). Slika božanske mudrosti koja stvara svijet radosno i uz igru, može označavati da Bog stvara zemlju radi užitka i radosti da bi se Bog igrao zajedno s čovjekom. Na isti način, kada čovjek živi pravedno i pošteno, ima pravo igrati se pred Bogom i slaviti ga svime što ima, što jest i što čini. ${ }^{33} \mathrm{U}$ 7. st. pr. Kr. prorok Izaija spominje i igranje s loptom: »Smotat će te u klupko, kao loptu te baciti po zemlji širokoj« (Iz 22, 18a). Moguće je da su Izraelci poznavali i bavili se takvim sportovima, ali nažalost za to nemamo dovoljno dokaza, već samo jezične natuknice koje nalazimo u biblijskim tekstovima. Zaključujući, moglo bi se reći da igra i ples u starozavjetnim tekstovima (iako rijetko spomenuti) prvotno čovjeku služe da bi se starozavjetni pojedinac i svojom tjelesnošću, a ne samo duhom, izrazio i usavršavao, dolazeći u kontakt s bližnjim i s Bogom. ${ }^{34}$ Metaforički gledano, ples i igra bili bi osobni odraz vjere kojim čovjek u radosti teži prema eshatološkoj sličnosti Bogu koji radosno pleše i igra se usred svog obnovljenog naroda (usp. Sef 3,17 ). ${ }^{35}$

\section{Trčanje i borba u Starom zavjetu}

Stari zavjet često spominje i uobičajenu ljudsku fizičku radnju trčanja koja se obično povezuje sa glasnicima neke vijesti ili s ratnicima. Hebrejski glagol

\footnotetext{
${ }^{31}$ Y-T. LEWINSKI, Games, u: F. SKOLNIK, M. BERENBAUM (ur.), Encyclopaedia Judaica, sv. VII, Farmington Hills (MI), Thomson Dale, ${ }^{2} 2007,370$.

${ }^{32}$ Usp. Novak, Kršćanstvo i sport..., 294.

${ }^{33}$ Isto, 294.

${ }^{34}$ Usp. Zovkić, Sportske igre kao izraz ljudske tjelesnosti..., 26.

35 »Jahve, Bog tvoj, u sredini je tvojoj, silni spasitelj! On će se radovati tebi pun veselja, obnovit će ti svoju ljubav, kliktat će nad tobom radosno.«
} 
רוּ ${ }^{36}$ (rûṣ) koji znači »trčati, žuriti, navaliti« opisuje ubrzanu, žurnu radnju trčanja, a subjekt trčanja su uglavnom ljudske noge (usp. Iz 59, 7; Izr 1, 16; 6, 18). Pojedinac je tako opisan da trči da bi što hitnije prenio neku vijest ili susreo neku osobu (usp. Post 24, 17.28; Br 11, 27; 2 Sam 18, 19-26; 1 Kr 19, 20; Pj 1, 4). Tako je i Božja riječ opisana kao da trči zemljom, a proroci su predstavljeni kao trkači Božje riječi: ${ }^{37}$ »Besjedu svoju šalje na zemlju, brzo trči riječ njegova» (Ps 147, 15); »Ne poslah ti proroka, a ipak trče! Ne govorih im, a ipak prorokuju!« (Jr 23, 21; usp. 14, 14; 27, 15; 29, 9).

Mudrosni tekstovi opisuju pravednika kao onoga koji trči Božjim putevima. U Ps 119 psalmist se zaklinje Gospodinu da trči putevima Zakona: »Ja trčim

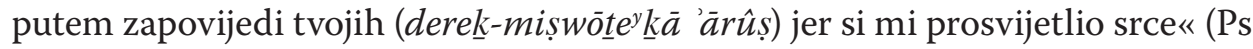
119, 32). Ovdje psalmist najvjerojatnije metaforički izriče svoj entuzijazam u korist i vjerodostojnost Zakona (Tore) kao puta kojim će doći do željenog cilja. ${ }^{38}$ Put mudrosti koji učenici uče od svojih učitelja prava je staza kojom pravednik može kročiti bez straha od posrtanja, za razliku od nevaljalaca čije noge posrću i trče prema zlu: »Noge njihove u zlo hitaju (lära yāruṣ̂u) i brze su da krv nevinu proliju « (Iz 59, 7; usp. Pr 1, 16); »Poučih te putu mudrosti, navratih te na prave staze; neće ti se zapletati koraci kad staneš hoditi; potrčǐ̌ li ( $w^{\prime}$ 'im-tārûsus), nećeš posrnuti« (Izr 4, 11-12).

Metaforički je slikom trke u Starom zavjetu također opisan i životni put, odnosno način moralnog ponašanja pojedinca, ali u negativnom kontekstu: ${ }^{39}$

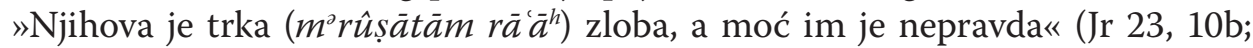
usp. Jr 8, 6).

Metafora trke $\left(m^{2} r \hat{u} s \bar{a}^{h}\right)$ je dakle jedna od slika kojom židovska misao opisuje život. Jer je Židov svjestan da dani čovjekovi prolaze kao sjena (usp. Ps 90, 4-6), zbog čega je potrebno na ovozemaljskom trkalištu živjeti prema putu koji nalaže Zakon Gospodinov.

U Starom zavjetu nalazi se još jedan važan sportski termin koji se može na-

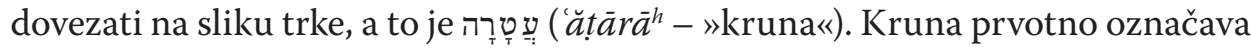
kraljevsku ili svećeničku vlast (usp. 2 Kr 12, 20; 1 Ljet 20, 2; Zah 6, 11.14), zatim postoji kruna koju nosi zaručnik (usp. Pj 3, 11) ili krune i vijenci koji su se nosili

\footnotetext{
${ }^{36}$ Glagol se pojavljuje 103 puta u Starom zavjetu: 96 u qalu; 6 u hifilu i jednom u pilpelu. Postoje također i dvije nominalne derivacije glagola s oblikovnim suglasnikom: mērôs i $m^{e} r u \hat{s} \bar{a}^{h}$ (P. MAIBERGER, רוּ - rûs, u: G. J. BOTTERWECK, H. RINGGREN, H.-J. FABRY (ur.), Theological Dictionary of the Old Testament, XIII, Grand Rapids (MI), Eerdmans, 2004, 416.

${ }^{37}$ Usp. Pfitzner, Paul and the Agon Motif..., 49.

${ }^{38}$ Maiberger, רוּ - rûs, 419.

${ }^{39}$ Isto, 422. Tragovi upotrebe metafore trčanja nalaze se i u rabinskoj literaturi, što s pozitivnom, što $\mathrm{s}$ negativnom konotacijom (prev. $a$.):
}

Ja trčim prema budućem životu, אני רץ לחיי העולם הבא

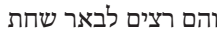
a oni trče prema jami propasti (bBer 28b). 
na slavljima (usp. Iz 28,1.3; Ez 23, 42). ${ }^{40}$ Kruna je ujedno i simbolički opisana kao nagrada koja se zadobiva kao vrhunac životne trke, naravno za pravednike: »U onaj dan Gospodin nad Vojskama postat će kruna slave i sjajan vijenac Ostatku svoga naroda $«(\mathrm{Iz} 28,5)$.

I sama je mudrost u kasnijoj svetopisamskoj predaji predstavljena kao krasan vijenac (usp. Sir 6, 31; 5, 6) koji čovjeku osigurava krunu slave (usp. Izr 4, 9). ${ }^{41}$ Mudrost je tako ona koja se bori s čovjekom i za čovjeka, slično kako se borio i Jakov kod Penuela (Post 32, 25; usp. Hoš 12, 5): »Mudrost je vjernike svoje spasila od nevolje (...) sačuvala ga od neprijatelja i zaštitila ga od zasjeda, darovala mu pobjedu u žestokom boju da spozna kako je bogobojaznost od

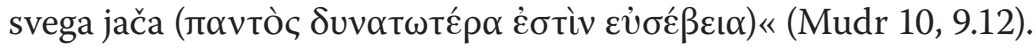

\section{Negativan aspekt sporta u Starom zavjetu}

Postupni razvoj biblijske kulture i jezika dovodi nas do razdoblja u kojemu se događa značajan susret židovske i grčke kulture. Helenizacija započeta dolaskom Aleksandra Velikog (331.-323.), a od početkom drugog stoljeća prije Krista, točnije 175. pr. Kr. dolaskom Antioha IV. Epifana, ona snažno utječe na židovsku kulturu i religiju. Na svim razinama društvenog i vjerskog života utjecaj je bio više negativan negoli pozitivan. ${ }^{42} \mathrm{U}$ odnosu na sport i sportske aktivnosti grčka se kultura uvelike razlikovala od židovske, jer su Grcima sport i sportske igre bili natjecateljskog karaktera, a ne kao Židovima potreba za fizičkom vježbom ili vojnim usavršavanjem. Prvi redak iz Knjige psalama »Blago čovjeku koji... ne sjeda u zbor podrugljivaca« (Ps 1,1a.c) moguće je povezati sa svima onima koji su se suzdržavali od sudjelovanja u borilištima i vježbalištima. ${ }^{43}$ Zamjetan je također i novi rječnik, ali i razvoj metafore (u našem slučaju povezan sa sportom) koji dobiva drugačije konotacije za vrijeme helenističkog judaizma. Snažan utjecaj na poimanje sportskog jezika i metafore imao je prijevod Starog zavjeta na grčki jezik (LXX). Tako, na primjer, čitamo u Prvoj knjizi o Makabejcima da se Alkim borio za velikosvećeničku čast (1 Mak 7, 21).

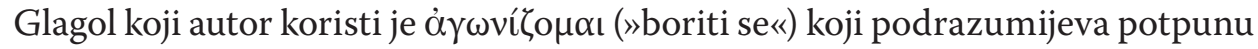
upotrebu snage i žestoku borbu za neki cilj. ${ }^{44}$ Istom se terminologijom koristi

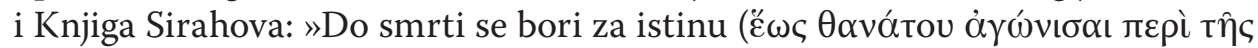
$\alpha \lambda \eta \theta \varepsilon i ́ \alpha \varsigma)$, i Gospod će se boriti za tebe« (Sir 4, 28).

U ovom posljednjem primjeru, glagol $\alpha \gamma \omega v i ́ \zeta o \mu \alpha ı$ stoji usporedno s glagolom по $\lambda \varepsilon \mu \varepsilon \imath \hat{~(» r a t o v a t i ; ~ b o r i t i ~ s e «), ~ s ̌ t o ~ o s l i k a v a ~ r a z v o j ~ u p o t r e b e ~ s p o r t s k e ~}$

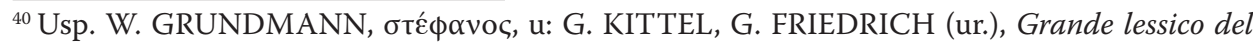
Nuovo Testamento, XII, Brescia, Paideia, 1979, 1100-1107.

${ }^{41}$ Usp. Pfitzner, Paul and the Agon Motif..., 54.

${ }^{42} \mathrm{O}$ razdoblju Antioha IV. Epifana i makabejskih pobuna može se čitati u 1-2 Mak.

${ }^{43}$ Usp. J. H. SILVER, Sports, u: F. SKOLNIK, M. BERENBAUM (ur.), Encyclopaedia Judaica, sv. XIX, Farmington Hills (MI), Thomson Dale, ${ }^{2} 2007,127-128$.

${ }^{44}$ Usp. Pfitzner, Paul and the Agon Motif..., 53.
} 
terminologije i terminologije igara, usmjeravajući rječnik prema područjima konflikata. Upitno je koliko se čitatelj ovih tekstova kroz ovakav rječnik podsjećao na napore sportaša u borilištima ili na trkalištima, ali sigurno je da su korištene riječi, istina, u svojem prenesenom značenju, izvorno odgovarale jeziku iz sportskog konteksta. ${ }^{45}$

\section{Zaključak}

Upotreba sportskoga jezika u Starom zavjetu je relativno progresivna. Sport se spominje već u uobičajenim riječima koje opisuju plesove povezane s kultom, preko riječi za igru pa sve do trke i borbe. Iako sport i igra u Starom zavjetu nemaju neku posebnu ulogu, one se spominju usputno unutar konteksta o čovjekovoj tjelesnosti. Starozavjetni čovjek se može igrati jer je tjelesan, ali svojom igrom on razvija otvorenost prema drugome, pri čemu su mu ples, igra i sport samo sredstvo za životnu igru pred Gospodinom. ${ }^{46}$

Nekoliko navedenih primjera o plesu, igri, trčanju i borbi, prema rječniku Starog zavjeta u nekom kontekstu predstavljaju sportski rječnik, ali i metaforu kojom se od potencijalnog skrivenog sportskog duha u izraelskom narodu želi oslikati život pravednika pred njegovim Stvoriteljem. Pravednik je onaj koji trčeći, odnosno živeći po Zakonu Gospodnjem, od njega prima nagradu, kao što govori psalmist: ${ }^{47} »$ On blagoslov prima od Gospodina i nagradu $\left(s^{2} \underline{d} \bar{a} q \bar{a}^{h}\right)$ od Boga, spasitelja svoga « (Ps 24, 5). Ta nagrada je izraz pravednosti i da bi je osvojio, potrebno se neprestano boriti, ponajviše kroz životne nevolje (vidi Jr 15, 15; Ps 69, 8.14; 139, 21): »Mnoge nevolje ima pravednik, ali ga Gospodin od svih izbavlja (Ps 34, 20); »Jer kao što se u vatri kuša zlato, tako i odabranici u peći poniženja« (Sir 2, 5). Gospodin podupire svoje pobožnike i zauzima se za njih. Život starozavjetnog čovjeka može se usporediti s borilištem u kojemu je pobožnik borac, njegovi suparnici su bezbožnici, a suborac i trener Gospodin: »Ne ponizuj se pred budalom i ne budi pristran pred mogućnicima. Do smrti se bori za istinu, i Gospod će se boriti za te« (Sir 4, 27-28). Kao što je Jakov pobijedio svojom pobožnošću i primio

\footnotetext{
${ }^{45}$ Usp. isto, 54; 62. Pod utjecajem filozofije, ponajviše stoicizma, sportskim jezikom i metaforama se u kasnijim spisima, ponajprije u 4 Mak, opisivala trka i borba za krepost pobožnosti. Ova se krepost postizala u vrijeme prvih mučenika kao plod borbe za vjeru sve do smrti (usp. 4 Mak 9, 23ss; 16, 16). Možda je jedan od najboljih primjera tekst iz 4 Mak 17, 11-16 (prev. a.): »Naime, uistinu bijaše sveta borba u koju su se oni stavili. Da, pred njih je postavljena nagrada (

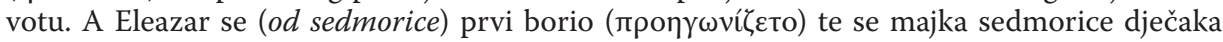
također uključila u borbu ( $\dot{\varepsilon} v \eta \dot{\theta} \theta \varepsilon \iota$ ), a i braća su se borila (

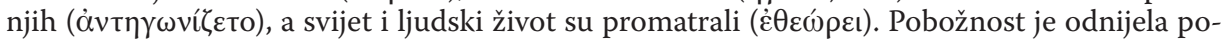
bjedu, okrunivši njezine borce ( $\dot{\varepsilon} \alpha u t \eta \hat{~} \varsigma \dot{\alpha} \theta \lambda \eta t \alpha े \varsigma ~ \sigma \tau \varepsilon \phi \alpha v o v ̂ \sigma \alpha)$. Tko se ne bi divio borcima za božanski zakon, tko ne bi bio zadivljen?«

${ }^{46}$ Usp. Zovkić, Sportske igre kao izraz ljudske tjelesnosti..., 31.

${ }^{47}$ Usp. Brändl, Der Agon bei Paulus..., 78.
} 
blagoslov (usp. Post 32, 23-32), tako može učiniti i svatko tko se poput brojnih starozavjetnih pravednika (npr. Job) bori za svoju egzistenciju.

Drugim riječima, u Starom zavjetu pronalazimo svakodnevne slike koje jednostavno, ali s mudrošću, obuzimaju starozavjetnu misao i starozavjetnog čovjeka, stvarajući metafore koje hermeneutski oblikovane doprinose dubljem razumijevanju svijeta i vjere onoga što je kovalo kasniju svetopisamsku predaju. Starozavjetni čovjek tako uistinu, dok pleše i igra se slavi Gospodina, ali također i trči i bori se za vjeru i sa vjerom na životnom borilištu kako bi se opravdao i postojano hodio u Zakonu Gospodnjem o kojemu misli dan i noć (usp. Ps 1, 2).

\section{Anđelo Maly* \\ Dance, Play, Fight or Run for a Faith. Sport Language as the Old Testament biblical Metaphor \\ Summary}

Every page of the Scripture is amazing and surprising. Sometimes one can understand what the sacred author intended, sometimes not. This principle is easier to apply within the pages of the New Testament, something that does not happen with texts from the Old Testament. A main reason seems to be a large distance from the culture, grammar and concepts of the OT. In other words, the language of the OT is more difficult than the language of the NT. In this article, author tries to illuminate some particularities of the Old Testament language, presenting in first instance few elements of the common language. Later, the author underlines functions of the language, particularly one of its important element, a metaphor. According to the author, a metaphor is something that fills the missing gaps in the language and it has to be contextualized in social and religious ambient. Since a Semitic way of thought and salvifichistorical nuances of the Old Testament language are particular, the author turns his research toward the cultural background of the OT as the context in which the metaphors are shaped. Among various contexts in the Old Testament, the one reserves special attention, and is that one of the game and sport, mostly overlooked. While dances and plays, a biblical man celebrates the Lord, but he also runs and fights for/with faith in the arena of his life just to affirm that he firmly walks in Lords Law and thus expresses his faith. Supporting his research with biblical citations, the author tries to explain how the Old Testament writers (and believers) used sport language not only as an authentic way of faith expression but also as a metaphor to explain their faith.

Key words: Old Testament, Semitic way of thought, metaphor, dance, play, sport, faith.

(na engl. prev. Anđelo Maly)

\footnotetext{
* Anđelo Maly, PhD, Postdoctoral Fellow at the Catholic Faculty of Theology, University of Zagreb; Address: Vlaška 38, pp 432, HR-10001 Zagreb, Croatia; E-mail: angel5bible@yahoo.com.
} 